\title{
Sahil Kuşağında ICARDA-CIMMYT Ekmeklik Buğday Genotiplerinin Verim ve Bazı Kalite Özellikleri Yönünden Karşılaştırılması
}

\author{
Ali KOÇ1, İlknur AKGÜN*2 \\ 1Batı Akdeniz Tarımsal Araștırma Enstitüsü Müdürlüğü,07000, Antalya \\ (ORCID: https://orcid.org/0000-0002-8744-5939) \\ 2Isparta Uygulamalı Bilimler Üniversitesi, Tarım Bilimleri ve Teknolojileri Fakültesi, Tarla Bitkileri Bölümü, \\ 32000, Isparta \\ (ORCID: https://orcid.org/0000-0002-7476-7226)
}

(Alınıș / Received: 13.09.2018, Kabul / Accepted: 15.02.2019, Online Yayınlanma / Published Online: 24.04.2019)

Anahtar Kelimeler Ekmeklik Buğday, Tane verimi, Glüten, Sedimentasyon Protein
Özet: Bu çalışmada, ekmeklik buğdayın yurt dıșı kaynaklı (ICARDA ve CIMMYT) 16 genotipi ile 4 kontrol çeşit (Pandas, Karatopak, Adana 99 ve Koç 2015) verim ve bazı kalite özellikleri (glüten, sedimentasyon ve ham protein) yönünden karşılaştırılmıştır. Araştırma, Antalya ekolojik koşullarında iki lokasyonda (Manavgat ve Aksu) tesadüf blokları deneme desenine göre $\mathrm{m}^{2}$ ye 500 tohum hesabıyla 4 tekrarlamalı olarak yürütülmüștür. Ekimle birlikte $30 \mathrm{~kg} / \mathrm{da}$ kompoze ( $6 \mathrm{~kg} \mathrm{~N}$ ve $6 \mathrm{~kg} / \mathrm{da}_{2} \mathrm{O}$ ) ve sapa kalkma döneminde $30 \mathrm{~kg} / \mathrm{da}$ amonyum nitrat ( $9.9 \mathrm{~kg} / \mathrm{da}$ saf $\mathrm{N}$ ) gübreleri uygulanmıștır. Araştırma sonucunda incelenen tüm özelliklerde genotipin etkisinin önemli olduğu belirlenmiştir. Lokasyonların etkisi ise tane verimi üzerine önemli iken, glüten, sedimentasyon ve ham protein oranına önemsiz bulunmuştur. Genotiplere göre tane verimi $722.60-1003.30 \mathrm{~kg} / \mathrm{da}$, glüten içeriği \% 25.1637.11; sedimantasyon değeri 25.50-45.25 ml ve ham protein oranı \%11.42-14.04 arasında değişmiştir. Sonuç olarak, bazı hatların kontrol olarak kullanılan çeşitlerden üstün olduğu belirlenmiștir. Özellikle tane verimi yönünden 11 (1003.30 kg/da) ve $3(1003.13 \mathrm{~kg} / \mathrm{da})$ nolu genotipler, protein oranı yönünden ise 15 nolu genotip ( \%14.04) tescil için önerilmiștir.

\section{Comparing Yield and Quality of ICARDA- CIMMYT Bread Wheat Lines in The Coastal Belt}

\section{Keywords}

Bread wheat

Grain yield

Gluten,

Sedimentation

Protein

\begin{abstract}
In this study was a compared control variety (Pandas, Karatopak, Adana 99 and Koç 2015) with 16 genotypes originating (ICARDA and CIMMYT) from abroad in the yield and some quality characteristics (gluten, sedimentation and crude protein). Research was established according to the randomized blocks design with 4 replicates as 500 seeds per $\mathrm{m}^{2}$ in two locations (Manavgat and Aksu) in the Antalya ecological conditions. $30 \mathrm{~kg} / \mathrm{da}$ compound fertilizer $\left(6 \mathrm{~kg} / \mathrm{da} \mathrm{N}\right.$ and $\left.6 \mathrm{~kg} / \mathrm{da} \mathrm{P}_{2} \mathrm{O}_{5}\right)$ was given with planting and at the stem elongation stage, $30 \mathrm{~kg} / \mathrm{da}$ ammonium nitrate $(9.9 \mathrm{~kg} / \mathrm{da} \mathrm{N})$ fertilizer was applied. In research results, it was determined that the effect of genotype is statistically significant in all the characteristics examined. While the effect of locations was significant in grain yield, it was in significant in gluten, sedimentation and crude protein ratio. According to the genotypes, grain yield is $722.60-1003.30 \mathrm{~kg} / \mathrm{da}$, gluten content is $25.16-37.11 \%$, sedimentation value is $25.50-45.25 \mathrm{ml}$ and crude protein rate is $42-14.04 \%$. As a result, it has been determined that some lines are superior from control varieties. Especially, line $11(1003.30 \mathrm{~kg} / \mathrm{da})$ and line $3(1003.13 \mathrm{~kg} / \mathrm{da})$ in grain yield and line $15(14.04 \%)$ for protein ratio were proposed for registration.
\end{abstract}

\section{Giriş}

Buğday, binlerce yıldır insanların temel enerji ve protein kaynağıdır. Dünya nüfusu tarafından günlük tüketilen kalorinin yaklașık olarak \%20'sini sağlamaktadır. Türkiye'de ise günlük enerji ihtiyacının ortalama $\% 44^{\prime}$ ü buğday ürünlerinden karşılanmaktadır [1]. Buğday, adaptasyon sınırının genişliği, mekanizasyonu, taşınması, depolanması ve işleme kolaylığı gibi sebeplerden dolayı tarımı yapılan 
kültür bitkileri içerisinde ilk sırada yer almaktadır. Ülkemizde buğday ekim alanı yaklaşı 7.7 milyon ha olup, 21.500 milyon ton ürün elde edilmekte ve dekara verim 280 kg'dır [2]. Bugün ülkemizde kullanılan tarım alanlarının yaklaşık \%50'sinde hububat ve bu tarım alanlarının 1/3'ünde ise sadece buğday üretilmektedir. Ancak son ylllarda buğday ekim alanlarında belirgin azalmalar gözlenerek ekim alanın 8 milyon hektarın altına inmiştir.

Batı Akdeniz Bölgesi 2.2 milyon da buğday ekim alanı ile ülkemiz buğday alanlarının yaklaşık \% 2.2'sini oluşturmaktadır [3]. Pamukta yaşanan ekonomik üretim darboğazı nedeniyle buğdaya büyük yönelim olmuștur. $\mathrm{Bu}$ durum üreticiyi son zamanlarda ekmeklik buğday yetiştiriciliğine yöneltmiş ve uygun çeşit arayışı hız kazanmıştır. Çeşidin ekolojik istekleri yanında kalitesi de önemli bir sorundur. Bölgede var olan un fabrikalarının çoğu ekmeklik buğday ihtiyaçlarını Orta Anadolu'dan karşılama yoluna gitmektedir. Buğdayın kalitesini tek bir unsur ile tanımlamak oldukça güçtür. Zira buğdayın kalitesi, çok sayıda faktörün etkisi altında oluşan bir özelliktir. Buğdayda kalite, ilgili meslek ya da tüketim gruplarının bulmayı istedikleri özelliklere göre değişiklikler göstermektedir. Tüccar hektolitre ağırlı̆̆ının ve safiyetinin yüksek olmasını ve bunlara ek olarak alıcısının istediği özelliklere sahip olan ürünü istemektedir. Çiftçi için verim, değirmenci için un randımanı önemlidir. Fırıncı için fazla kabaran, bol su çeken, ekmek verimi yüksek olan un tercih edilmektedir [4]. Farklı ekolojik koşullara sahip ülkemizde, uygun çeşit seçimi ve kültürel uygulamaların verim ve kalite üzerine olan etkisini belirlemek üzere farklı yıllarda birçok çalışma yapılmıştır.

Günümüzde üretim azalmakta ve artan nüfusun beslenmesi her geçen gün daha da zorlașmaktadır. Birim alandan fazla verimin alınmasında, bölge ekolojik koşullarına iyi uyum gösteren yeni çeşitlerin geliştirilmesi gerekmektedir.

Bu araştırmada sahil kuşağı Araştırma Enstitülerinin geliştirmiş olduğu çeșitler, CIMMYT ve ICARDA'dan son yillarda temin edilen durulmuş genotiplerle verim ve kalite yönünden karşılaştırılmıştır.

\section{Materyal ve Metot}

$\mathrm{Bu}$ araștırma Batı Akdeniz Tarımsal Araștırma Enstitüsü tarla bitkileri araștırma ve deneme alanı ile Manavgat ilçesi Seydiler mahallesi çiftçi arazisinde 2016-17 vejetasyon döneminde yürütülmüștür. Çalışmada, uluslararası araştırma kuruluşlarından adaptasyonu sağlanmış ileri kademe 16 hat ve 4 ekmeklik buğday çeşidi (Pandas, Adana 99, Karatopak ve Koç 2015) materyal olarak kullanılmıştır (Tablo 1).
Tablo 1. Araștırmada kullanılan ekmeklik buğday genotipleri ve orijinleri

\begin{tabular}{|c|l|c|l|}
\hline No & $\begin{array}{c}\text { Genotip Adı veya } \\
\text { Menşei }\end{array}$ & No & \multicolumn{1}{|c|}{$\begin{array}{c}\text { Genotip Adı veya } \\
\text { Menşei }\end{array}$} \\
\hline 1 & CIMMYT23HRWYT18 & 11 & CIMMYT22HRWYT208 \\
\hline 2 & CIMMYT23HRWYT34 & 12 & CIMMYT7THWSN4414 \\
\hline 3 & CIMMYT23HRWYT39 & 13 & CIMMYT7THWSN4526 \\
\hline 4 & CIMMYT23HRWYT41 & 14 & CIMMYT22HRWYT28 \\
\hline 5 & CIMMYT14HTWYT17 & 15 & CIMMYT33ESWYT139 \\
\hline 6 & CIMMYT14HTWYT30 & 16 & ICARDAYAZ183 \\
\hline 7 & CIMMYT23SAWYT23 & 17 & KARATOPAK \\
\hline 8 & CIMMYT23SAWYT36 & 18 & ADANA99 \\
\hline 9 & CIMMYT36ESWYT23 & 19 & KOÇ 2015 \\
\hline 10 & CIMMYT36ESWYT36 & 20 & PANDAS \\
\hline
\end{tabular}

Çalışma tesadüf blokları deneme desenine göre, 4 tekrarlamalı olarak yürütülmüştür. Parsel alanı 7.2 $\mathrm{m}^{2}$, hasat alanı ise $6 \mathrm{~m}^{2}$ 'dir. Ekim ișlemi $\mathrm{m}^{2}$ ' ye 500 tohum hesabıyla deneme mibzeri ile ve Kasım ayı içerisinde yapılmıştır. Ekimle birlikte $30 \mathrm{~kg} / \mathrm{da}$ kompoze gübresi (6 $\mathrm{kg} \mathrm{N}$ ve $6 \mathrm{~kg} / \mathrm{da}$ fosfor), kardeşlenme dönemi sonu sapa kalkma döneminde ise $30 \mathrm{~kg} / \mathrm{da}$ amonyum nitrat üsten $(9.9 \mathrm{~kg} / \mathrm{da} \mathrm{N})$ verilmiştir. Yabancı ot mücadelesi için şubat ayı içinde $30 \mathrm{ml} /$ da olacak şekilde üsten Mesosulfuran seçici herbisiti uygulanmıștır. Deneme hasadı parsel biçerdöveri ile mayıs ayı sonunda yapılmıștır.

Araştırmada tane verimi ve bazı kalite özellikleri incelenmiştir. Tane verimi, parsel biçerdöveri ile parselin $6 \mathrm{~m}^{2}$ hasat edilmiş ve alınan materyal $\mathrm{kg} / \mathrm{da}$ birimine çevrilerek tane verimi hesaplanmıștır. Unda sedimantasyon ve yaş glüten (öz) miktarı analizleri Özkaya ve Özkaya [5] tarafından belirtilen esaslara göre yapılmıştır. Tanede protein oranı (\%), Kjeldahl yöntemi ile azot içeriği belirlenmiş ve 6.25 katsayısı ile çarpılarak hesaplanmıştır [6].

Araştırmanın yürütüldüğü 2016-2017 vejetasyon dönemine (Ekim-Haziran) ait sıcaklık $\left({ }^{\circ} \mathrm{C}\right)$ ve yağıȘ (mm) değerleri Tablo 2'de verilmiştir [7]. 2016- 2017 üretim sezonunda bölgemizdeki yağış miktarı (440.40 $\mathrm{mm})$ uzun yıllar ortalamasından $(1098 \mathrm{~mm})$ daha düşük, ortalama sıcaklık ise daha yüksektir (uzun yıllar sıcaklık ortalaması $15.28^{\circ} \mathrm{C}$; üretim sezonunda ortalama sicaklık $16.62^{\circ} \mathrm{C}$ ).

Elde edilen verilerin varyans analizi, deneme desenine uygun olarak SAS (1999) programında ve ortalamalar arasındaki karşılaştırmalar Duncan çoklu karşılaştırma testine göre yapılmıştır.

\section{Bulgular ve Tartışma}

\subsection{Tane Verimi}

Farklı lokasyonlarda yetiştirilen ekmeklik buğday genotiplerinde dekara tane verimi üzerine çeşit ve lokasyonun etkisi önemli $(\mathrm{P} \leq 0.01)$ lokasyon $\mathrm{x}$ çeşit interaksiyonu ise önemsiz bulunmuştur. 
Tablo 2. Antalya ilinin denemenin yürütüldüğü döneme ve uzun yıllara ait önemli iklim verileri

\begin{tabular}{|l|l|l|l|l|l|l|l|l|}
\hline \multirow{2}{*}{ Aylar } & Ort. Sicak. $\left.{ }^{\circ} \mathrm{C}\right)$ & Ort.Min. Sicak $\left({ }^{\circ} \mathrm{C}\right)$ & Ort. Max. Sicak $\left({ }^{\circ} \mathrm{C}\right)$ & \multicolumn{1}{l|}{ Top. Yağış (mm) } \\
\cline { 2 - 9 } & $1950-2016-2016-2017$ & $1950--2016$ & $2016-2017$ & $1950--2016$ & $2016-2017$ & $1950--2016$ & $2016-2017$ \\
\hline Ekim & 18.0 & 22.7 & 14.5 & 18.6 & 26.9 & 32.2 & 76.2 & 0.0 \\
Kasım & 15.1 & 16.2 & 7 & 7.8 & 32.7 & 32.1 & 123.7 & 26.2 \\
Aralık & 10.7 & 11.1 & 6.8 & 6.9 & 16.2 & 18.1 & 279.1 & 21.1 \\
Ocak & 9.9 & 10.2 & 6 & 5.8 & 14.9 & 15.1 & 236.3 & 211.4 \\
Subat & 9.2 & 11.1 & 5.1 & 2.2 & 14.9 & 24.3 & 195.5 & 8.8 \\
Mart & 12.6 & 13.5 & 8.0 & 5.2 & 17.8 & 24.6 & 94.1 & 95 \\
Nisan & 16.2 & 16.4 & 11.2 & 11.4 & 21.3 & 23.1 & 52.5 & 23.4 \\
Mayıs & 20.5 & 22.2 & 15.1 & 15.7 & 25.6 & 26.3 & 31.5 & 53.3 \\
Haziran & 25.3 & 26.2 & 19.6 & 18.8 & 30.8 & 32.2 & 9.4 & 1.2 \\
\hline Ort./ Top. & 15.28 & 16.62 & 10.37 & 10.27 & 22.34 & 25.33 & 1098.3 & 440.4 \\
\hline
\end{tabular}

Ekmeklik buğday genotiplerinde lokasyonlar ortalaması tane verimi $722.60-1003.30 \mathrm{~kg} / \mathrm{da}$ arasında değișmiștir. En fazla birim alan verimi 11 ve 3 nolu genotiplerden elde edilmiștir. Bu genotipler ile 2,10 ve 5 nolu genotipler arasinda istatistiksel olarak önemli farklılık bulunmamıștır. En az tane verimi ise Pandas ve Adana-99 çeşitlerinden elde edilmiş ve istatistiksel olarak aynı grupta yer almışlardır (Tablo $3)$.

Araştırmada dekara tane verimi lokasyonlara göre önemli farklılık göstermiș ve Manavgat lokasyonunda (919.95 kg/da) daha yüksek değer elde edilmiștir. Aksu lokasyonunda ortalama verim $895.47 \mathrm{~kg} / \mathrm{da}$ olarak belirlenmiștir. Ekmeklik buğday genotiplerinin lokasyonlara vermiş olduğu tepki benzer olduğundan interaksiyon önemli bulunmamıştır. Her iki lokasyoda da 11 ve 3 nolu genotiplerden en yüksek tane verimi elde edilmiştir.

Tane verimi, genotip ile çevre faktörlerinin karşllıklı etkileşimi sonucu ortaya çıkmaktadır. Yine tahıllarda başaktaki tane verimi ve $\mathrm{m}^{2}$ de başak sayısı verimi etkileyen faktörler arasındadır. Tonk ve ark., [8] tarafından yapılan çalışmada tane verimine en fazla doğrudan olumlu yönde etkiyi, $\mathrm{m}^{2}$ de başak sayısı verdiğini bildirmişlerdir.

$\mathrm{Bu}$ araştırmada elde ettiğimiz sonuçlara benzer olarak, tane veriminin genotiplere göre değiștiğini farklı çalışmalarda ortaya konulmuştur. Ekmeklik buğday genotiplerinde tane veriminin Özseven ve Bayram [9] 408.9-638.1 kg/da; Kahraman [10] 537.0$812.8 \mathrm{~kg} /$ da arasında değiștiğini bildirmişlerdir.

Tane verimi ekolojik şartlara ve uygulanan kültürel işlemlere göre de değișebilmektedir. Ekmeklik buğdayın farklı çeşit ve hatları kullanılarak yapılan çalışmada, ortalama tane verimi Samsun lokasyonunda $345.0 \mathrm{~kg} / \mathrm{da}$, Amasya lokasyonunda ise $486.3 \mathrm{~kg} / \mathrm{da}$ olarak belirlenmiştir [11]. Yine 25 ekmeklik buğday genotipi (5 çeşit ve 20 genotip) Samsun ve Amasya lokasyonlarinda denemeye alınmış ve ortalama tane veriminin $286.7-572.0 \mathrm{~kg} / \mathrm{da}$ arasında değiştiği bildirilmiştir. Araştırıcılar seçilecek genotiplerin farklı çevre şartlarına uygun ve çevre varyasyonundan en az etkilenen bir genetik yapıya sahip olmaları gerektiğini vurgulamışlardır [12].

Tablo 3. Farklı lokasyonlarda yetiștirilen ekmeklik buğday genotiplerinde tane verimine $(\mathrm{kg} / \mathrm{da})$ ait ortalamalar

\begin{tabular}{|l|lll|}
\hline Hat /Çeşitler & Aksu & Manavgat & Ortalama $^{1}$ \\
\hline 11 & 967.36 & 1039.24 & $1003.30 \mathrm{~A}$ \\
3 & 956.94 & 1049.31 & $1003.13 \mathrm{~A}$ \\
2 & 954.17 & 1014.58 & $984.36 \mathrm{AB}$ \\
10 & 954.56 & 956.54 & $955.35 \mathrm{~A}-\mathrm{C}$ \\
5 & 948.61 & 948.00 & $948.31 \mathrm{~A}-\mathrm{D}$ \\
14 & 943.00 & 945.20 & $944.10 \mathrm{~B}-\mathrm{E}$ \\
15 & 929.86 & 955.90 & $942.88 \mathrm{~B}-\mathrm{E}$ \\
4 & 907.64 & 977.08 & $942.36 \mathrm{~B}-\mathrm{E}$ \\
9 & 926.91 & 920.31 & $923.61 \mathrm{C}-\mathrm{F}$ \\
16 & 894.44 & 938.19 & $916.33 \mathrm{C}-\mathrm{F}$ \\
13 & 877.08 & 939.93 & $908.5 \mathrm{C}-\mathrm{E}$ \\
Koç 2015 & 906.62 & 908.64 & $907.63 \mathrm{D}-\mathrm{F}$ \\
8 & 893.56 & 899.50 & $896.53 \mathrm{D}-\mathrm{F}$ \\
1 & 869.44 & 911.81 & $890.63 \mathrm{EF}$ \\
6 & 889.38 & 890.82 & $890.10 \mathrm{EF}$ \\
Karatopak & 882.56 & 878.65 & $880.60 \mathrm{~F}$ \\
12 & 859.03 & 878.82 & $868.90 \mathrm{~F}$ \\
7 & 857.99 & 878.47 & $868.20 \mathrm{~F}$ \\
Adana-99 & 756.20 & 757.90 & $757.10 \mathrm{G}$ \\
Pandas & 734.03 & 710.07 & $722.60 \mathrm{G}$ \\
\hline Lokasyon Ort. & 895.47 & 919.95 & 907.72 \\
\hline LSD & & & 17.53 \\
\hline CV (\%) & & & 6.16 \\
\hline
\end{tabular}

${ }^{1}$ Aynı sütunda aynı harfle gösterilen ortalamalar arasındaki farklılık önemli değildir.

\subsection{Yaş Gluten İçeriği ve Zeleny Sedimentasyon Değeri}

Farklı lokasyonlarda yetiştirilen ekmeklik buğday genotiplerinde glüten miktarı (\%) üzerine çeşidin etkisi önemli $(\mathrm{P} \leq 0.01)$, lokasyon ve lokasyon $\mathrm{x}$ çeşit interaksiyonu ise önemsiz bulunmuştur. Farklı ekmeklik buğday çeşitlerinin, glüten miktarına ait ortalama değerler Tablo 4'de verilmiștir.

İki farklı lokasyonda yetiştirilen ekmeklik buğday genotiplerinde glüten oranı \% 25.16-37.11 arasında değişmiştir. En yüksek glüten oranı 7 nolu hatta belirlenmiş ve bu hat ile Pandas çeşidi (\%35.23) arasındaki, farklılıklar önemli bulunmamıştır. En az glüten değeri 4 nolu hatta belirlenmiş, bu hat ile 8 
(\%26.57), Adana 99 (\%26.61) ve 12 (\%27.18) nolu genotipler aynı grupta yer almıştır.

Tablo 4. Farklı lokasyonlarda yetiştirilen ekmeklik buğday genotiplerinde glüten içeriğine (\%) ait ortalamaları

\begin{tabular}{|l|lll|}
\hline Hat/Çeşitler & Aksu & Manavgat & Ortalama \\
\hline 7 & 36.00 & 38.22 & $37.11 \mathrm{~A}$ \\
Pandas & 34.97 & 35.50 & $35.23 \mathrm{AB}$ \\
15 & 33.42 & 35.85 & $34.63 \mathrm{~B}$ \\
5 & 34.95 & 33.30 & $34.12 \mathrm{BC}$ \\
6 & 33.25 & 33.57 & $33.41 \mathrm{~B}-\mathrm{D}$ \\
3 & 31.85 & 32.77 & $32.31 \mathrm{C}-\mathrm{E}$ \\
13 & 31.70 & 32.17 & $31.93 \mathrm{C}-\mathrm{E}$ \\
10 & 33.27 & 30.40 & $31.83 \mathrm{DE}$ \\
Koç 2015 & 31.05 & 32.17 & $31.61 \mathrm{DE}$ \\
1 & 31.10 & 31.72 & $31.41 \mathrm{DE}$ \\
Karatopak & 30.65 & 31.45 & $30.05 \mathrm{E}$ \\
16 & 31.22 & 30.47 & $30.85 \mathrm{E}$ \\
11 & 32.62 & 27.82 & $30.22 \mathrm{EF}$ \\
14 & 28.12 & 28.50 & $28.31 \mathrm{FG}$ \\
9 & 25.90 & 29.62 & $27.76 \mathrm{G}$ \\
2 & 27.62 & 27.87 & $27.75 \mathrm{G}$ \\
12 & 27.45 & 26.92 & $27.18 \mathrm{GH}$ \\
Adana99 & 26.67 & 26.55 & $26.61 \mathrm{GH}$ \\
8 & 27.20 & 25.95 & $26.57 \mathrm{GH}$ \\
4 & 25.47 & 24.85 & $25.16 \mathrm{H}$ \\
\hline Lokasyon Ort. & 30.72 & 30.78 & 30.75 \\
\hline LSD & & & 2.22 \\
\hline CV(\%) & & & 7.30 \\
\hline
\end{tabular}

${ }^{1}$ Aynı sütunda aynı harfle gösterilen ortalamalar arasındaki farklılık önemli değildir.

Araștırmada lokasyonlara göre ortalama glüten içeriği benzer olmuş ve Manavgat'ta \% 30.78, Aksu'da \% 30.72 olarak belirlenmiştir.

Ekmeklik buğday glüten önemli bir kalite kriteridir. Islah edilen çeşitlerde glüten içeriğinin yüksek ve bölgelere göre stabil olması istenmektedir. Ekmeklik buğdayda unda yaş glüten oranı $\% 35$ ve üstünde ise yüksek, \% 28-35 iyi, \% 20-27 orta ve \%20'den az ise düşük olarak kabul edilmektedir [13]. Bu verilere göre 7 ve 15 nolu hatlar ve Pandas çeşidi her iki lokasyonda da ilk grupta yer aldıklarından stabilitesinin daha yüksek ve \% 35'in üstünde yaş glüten oranına sahip olması un kalitesinin yüksek olduğunu göstermektedir.

$\mathrm{Bu}$ konuda yapılan araştırmalar incelendiğinde, ekmeklik buğday genotiplerinde Işık [14], glüten oranının \% 24.72-34.27 ve sedimantasyon değerinin 30.77-60.83 ml, Aydoğan ve Soylu [15] Zeleny sedimantasyon değerini sulu şartlarda $31.0-51.0 \mathrm{ml}$, kuru şartlarda ise $26.0-39.5 \mathrm{ml}$ arasında değiştiğini bildirmişlerdir.

Buğdayda sedimantasyon değeri üzerine çeşit ve lokasyon $\mathrm{x}$ çeşit interaksiyonu önemli bulunmuştur $(\mathrm{P} \leq 0.01)$. Farklı lokasyonda yetiştirilen ekmeklik buğday genotiplerinde ortalama sedimantasyon değeri 25.50-45.5 ml arasında değişmiştir. En yüksek sedim değeri, Adana 99 çeșidinden elde edilmiș, bunu Karatopak (44.12 ml) , $10(44.12 \mathrm{ml})$ ve 12 nolu genotipler (43.12 ml) izlemiş, bu genotipler arasındaki farklılık önemli bulunmamıștır. En düșük sedim değeri ise 14 nolu genotipte belirlenmiş, bunu $7(26.62 \mathrm{ml})$, $15(26.87 \mathrm{ml})$ ve $2(27.62 \mathrm{ml})$ nolu genotipler takip etmiştir. Bu genotipler istatistiksel olarak aynı grupta yer almıştır (Tablo 5).

Araştırmada glüten içeriğine benzer olarak, sedimantasyon değerinde de lokasyon önemli bulunmamıştır (Aksu $35.40 \mathrm{ml}$; Manavgat $34.72 \mathrm{ml}$ ). Ancak lokasyonlarda genotiplerin tepkisi farklı olduğundan interaksiyon önemli olmuștur. Farklı ekmeklik buğday genotiplerinin sedim değeri Aksu lokasyonunda 22.00-46.00 $\mathrm{ml}$ Manavgat lokasyonunda ise 24.75-45.50 $\mathrm{ml}$ arasinda değişmiştir. Aksu ve Manavgat lokasyonlarında Adana 99 ve Karatopak çeşitleri ile 10 ve 12 numaralı genotiplerde yüksek sedimantasyon değerleri belirlenmiştir (Tablo 5).

Glüten kalitesini belirleyen testlerden birisi de, sedimentasyon değeridir. Elgün ve ark., [16] bildirdiğine göre, sedimentasyon değeri $15 \mathrm{ml}$ 'den az olanlar çok zayıf, 16-24 ml arasındakiler zayıf, 25-36 $\mathrm{ml}$ arasında olanlar iyi, $36 \mathrm{ml}$ 'den yüksek olanlar ise çok iyi glüten kalitesine sahiptir. Bu değerlendirmeye göre, denemeye alınan hat/çeşitlerin tamamının iki yıllık ortalamalarına göre, iyi ve çok iyi glüten kalitesine sahip olduğu görülmektedir. Araştırmada buğday genotiplerinin lokasyonlara tepkisi farklı olduğundan 14 (Aksu) ve 7 (Manavgat) nolu genotiplerde sedimentasyon değeri $25 \mathrm{ml}$ altına düşmüştür.

Tablo 5. Farklı lokasyonlarda yetiștirilen ekmeklik buğday genotiplerinde Zeleny sedimantasyon değerine (ml) ait ortalamalar

\begin{tabular}{|l|lll|}
\hline Hat /Çeşitler & Aksu & Manavgat & Ortalama \\
\hline Adana99 & $45.00 \mathrm{ab}^{1}$ & $45.50 \mathrm{a}^{1}$ & $45.25 \mathrm{~A}^{1}$ \\
10 & $43.25 \mathrm{a}-\mathrm{c}$ & $45.00 \mathrm{a}$ & $44.12 \mathrm{~A}$ \\
Karatopak & $45.75 \mathrm{a}$ & $42.50 \mathrm{ab}$ & $44.12 \mathrm{~A}$ \\
12 & $46.00 \mathrm{a}$ & $40.25 \mathrm{a}-\mathrm{c}$ & $43.12 \mathrm{AB}$ \\
8 & $39.25 \mathrm{~d}$ & $42.25 \mathrm{ab}$ & $40.75 \mathrm{BC}$ \\
16 & $40.75 \mathrm{~cd}$ & $39.25 \mathrm{bc}$ & $40.00 \mathrm{C}$ \\
1 & $40.50 \mathrm{~cd}$ & $37.75 \mathrm{~b}-\mathrm{d}$ & $39.12 \mathrm{CD}$ \\
6 & $39.75 \mathrm{~d}$ & $36.00 \mathrm{c}-\mathrm{f}$ & $37.87 \mathrm{CD}$ \\
13 & $42.75 \mathrm{bc}$ & $30.25 \mathrm{gh}$ & $36.50 \mathrm{DE}$ \\
9 & $30.75 \mathrm{f}-\mathrm{h}$ & $37.00 \mathrm{~b}-\mathrm{e}$ & $33.87 \mathrm{EF}$ \\
4 & $36.25 \mathrm{e}$ & $31.00 \mathrm{fg}$ & $33.62 \mathrm{EF}$ \\
Pandas & $33.25 \mathrm{f}$ & $30.00 \mathrm{gh}$ & $31.62 \mathrm{~F}$ \\
3 & $29.75 \mathrm{~g}-1$ & $33.00 \mathrm{~d}-\mathrm{g}$ & $31.37 \mathrm{~F}$ \\
11 & $31.75 \mathrm{fg}$ & $30.75 \mathrm{fg}$ & $31.25 \mathrm{~F}$ \\
5 & $30.25 \mathrm{gh}$ & $31.75 \mathrm{e}-\mathrm{g}$ & $31.00 \mathrm{~F}$ \\
Koç 2015 & $29.25 \mathrm{gl}$ & $32.75 \mathrm{~d}-\mathrm{g}$ & $31.00 \mathrm{~F}$ \\
2 & $27.25 \mathrm{ij}$ & $28.00 \mathrm{gh}$ & $27.62 \mathrm{G}$ \\
15 & $26.00 \mathrm{j}$ & $27.75 \mathrm{gh}$ & $26.87 \mathrm{G}$ \\
7 & $28.50 \mathrm{~h}-\mathrm{j}$ & $24.75 \mathrm{~h}$ & $26.62 \mathrm{G}$ \\
14 & $22.00 \mathrm{k}$ & $29.00 \mathrm{gh}$ & $25.50 \mathrm{G}$ \\
\hline Lokasyon Ort. & 35.40 & 34.72 & 35.06 \\
\hline LSD & 2.79 & 5.59 & 3.09 \\
\hline CV(\%) & 5.57 & 11.38 & 8.90 \\
\hline Aynı sütunda aynı & harfle gösterilen ortalamalar arasındaki farkl11lk \\
önemli değildir. & & & \\
& & & \\
\hline
\end{tabular}


Ekmeklik buğday ıslah çalışmalarında kalite yönünden üzerinde önemle durulan Zeleny sedimantasyon, protein miktar ve kalitesinin göstergesidir. Aynı protein oranına sahip buğday çeşitlerinin, Zeleny sedimentasyon değeri, protein kalitesine bağlı olarak farklı olabilmektedir. Bu çalışmada bazı genotiplerin, tane protein oranları birbirine çok yakın iken, (örnek 15 nolu genotip ile Pandas çeşidi) Zeleny sedimentasyon sonuçları farklılık göstermiştir.

Araștırmalarda protein ve glüten oranı arasındaki korelasyonun pozitif olduğu görülmektedir. Ancak proteinlerin oransal olarak fazla olmass, protein kalitesinin yüksek olduğu anlamına gelmemektedir. Çevresel etmenler, süne zararı ve genetik faktörlerden kaynaklanan nedenlere bağlı olarak proteinlerin yapisında bozulmalar meydana gelebilmektedir [17].

\subsection{Ham Protein Oranı}

Ekmeklik buğday genotiplerinde ortalama tanedeki protein oranı \%11.42-14.04 arasında değişmiş ve bu farklılık önemli bulunmuştur $(\mathrm{P} \leq 0.01)$. En fazla protein oran 15 nolu genotipi belirlenmiş, bu genotip ile Pandas (\%13.47) çeşidi arasındaki farklılık önemli olmamıștır. En az protein oranı ise 9 nolu genotipte tespit edilmiştir. Bu genotipi Adana 99 (\%11.69), 2 $(\% 11.75)$ ve 3 (\%11.95) buğday genotipleri istatistiksel olarak aynı grupta yer almıştır (Tablo 6).

Tablo 6. Farklı lokasyonlarda yetiştirilen ekmeklik buğday genotiplerinde tanede protein oranına (\%) ait ortalamalar

\begin{tabular}{|l|lll|}
\hline Hat/Çeșitler & Aksu & Manavgat & Ortalama \\
\hline 15 & $14.02 \mathrm{a}^{1}$ & $14.05 \mathrm{a}^{1}$ & $14.04 \mathrm{~A}^{1}$ \\
Pandas & $13.47 \mathrm{a}-\mathrm{c}$ & $13.42 \mathrm{bc}$ & $13.45 \mathrm{AB}$ \\
14 & $13.72 \mathrm{ab}$ & $13.10 \mathrm{~cd}$ & $13.41 \mathrm{~B}-\mathrm{D}$ \\
11 & $13.20 \mathrm{~b}-\mathrm{d}$ & $13.45 \mathrm{bc}$ & $13.33 \mathrm{BC}$ \\
10 & $13.02 \mathrm{c}-\mathrm{e}$ & $13.57 \mathrm{a}-\mathrm{c}$ & $13.30 \mathrm{BC}$ \\
Koç 2015 & $13.85 \mathrm{ab}$ & $12.67 \mathrm{~d}-\mathrm{f}$ & $13.26 \mathrm{BC}$ \\
Karatopak & $12.50 \mathrm{ef}$ & $13.87 \mathrm{ab}$ & $13.18 \mathrm{~B}-\mathrm{E}$ \\
6 & $12.80 \mathrm{c}-\mathrm{f}$ & $13.22 \mathrm{~cd}$ & $13.01 \mathrm{C}-\mathrm{F}$ \\
12 & $12.40 \mathrm{ef}$ & $13.17 \mathrm{~cd}$ & $12.78 \mathrm{E}-\mathrm{G}$ \\
16 & $12.72 \mathrm{~d}-\mathrm{f}$ & $12.80 \mathrm{de}$ & $12.76 \mathrm{D}-\mathrm{G}$ \\
4 & $13.25 \mathrm{~b}-\mathrm{d}$ & $12.20 \mathrm{fg}$ & $12.72 \mathrm{~F}-\mathrm{H}$ \\
8 & $12.20 \mathrm{f}$ & $13.22 \mathrm{~cd}$ & $12.71 \mathrm{~F}-\mathrm{H}$ \\
1 & $12.40 \mathrm{ef}$ & $12.25 \mathrm{e}-\mathrm{g}$ & $12.32 \mathrm{G}-\mathrm{I}$ \\
7 & $12.47 \mathrm{ef}$ & $12.07 \mathrm{~g}$ & $12.27 \mathrm{G}-\mathrm{I}$ \\
13 & $11.32 \mathrm{~g}$ & $13.05 \mathrm{~cd}$ & $12.19 \mathrm{H}-\mathrm{J}$ \\
5 & $12.42 \mathrm{ef}$ & $11.87 \mathrm{~g}$ & $12.14 \mathrm{H}-\mathrm{J}$ \\
3 & $11.47 \mathrm{~g}$ & $12.42 \mathrm{e}-\mathrm{g}$ & $11.95 \mathrm{I}-\mathrm{K}$ \\
2 & $12.30 \mathrm{f}$ & $11.20 \mathrm{~h}$ & $11.75 \mathrm{JK}$ \\
Adana99 & $12.27 \mathrm{f}$ & $11.10 \mathrm{hl}$ & $11.69 \mathrm{~J}-\mathrm{K}$ \\
\hline & $12.25 \mathrm{f}$ & $10.60 \mathrm{l}$ & $11.42 \mathrm{~K}$ \\
\hline Lokasyon Ort. & 12.70 & 12.66 & 12.73 \\
\hline LSD & 0.68 & 0.56 & 0.50 \\
\hline CV(\% ) & 3.79 & 3.13 & 3.96 \\
\hline
\end{tabular}

${ }^{1}$ Aynı sütunda aynı harfle gösterilen ortalamalar arasındaki farklılık önemli değildir.

Araştırmada farklı ekmeklik buğday genotiplerinin protein oranı lokasyonlara göre önemli farklılık göstermemiştir (lokasyonun ortalaması; Aksu
\%12.70; Manavgat \% 12.66). Ancak lokasyonlardaki çevre şartlarına genotiplerin tepkisi farklı olduğundan interaksiyon önemli bulunmuştur. Genel ortalama olarak Aksu lokasyonunda farklı ekmeklik buğday genotiplerinin protein oranı \% 11.32-14.02, Manavgat lokasyonunda ise \% 10.60-14.05 arasında değişmiştir (Tablo 6).

Protein oranı buğdayda istenilen kalite özelliklerinde birisidir. Protein oranı tane dolum dönemindeki sıcaklığa, yağıș ve gübreleme ile yetiștirme tekniklerine, sulama miktarı ve zamanına göre değișiklik göstermektedir [18]. Yine buğdayda protein oranının tür, çeşit çevre koşulları ve üretim tekniğine bağlı olarak değişebildiği, yurdumuzda protein oranının topbaşlarda \% 9-13, ekmeklik buğdaylarda \% 10-15, makarnalık buğdaylarda \% 11-17 arasında olduğu bildirilmiştir [13];[15].

İki lokasyonda (Konya ve Çumra) 20 ekmeklik buğday genotipi kullanılarak yapılan çalıșmada, protein oranının genotip ve lokasyonlara göre \% 9.83-14.,10 arasında değiștiği, protein oranının kullanım amacını etkileyen en önemli özellik olduğunu bildirilmiştir. Protein oranı ile tane verimi arasında olumsuz ve önemli $(r=-0,4426)$ korelasyon belirlenmiştir [19].

Yukardaki bulgularla sonuçlarımız benzerlik göstermekte ve verimi yüksek olan buğday genotiplerinde tanedeki protein oranı da düşük bulunmuştur.

\section{Sonuç}

$\mathrm{Bu}$ araștırmada, ileri kademedeki genotiplerin, kontrol olarak kullanılan çeşitlerden üstün özellikler gösterdiği, bu genotiplerin, yeni çeşitlerin geliştirilmesinde ebeveyn olarak kullanılması veya bazılarının (tane verimi yönünden 11 ve 3 nolu genotipler; protein oranı yönünden 15 nolu genotip) tescile önerilebileceği belirlenmiştir.

\section{Teşekkür}

Bu çalıșma ilk yazarın (A. Koç) yüksek lisans tezinin bir bölümüdür.

\section{Kaynakça}

[1] Yurdakök K., İnce, O. T. 2009. Çocuklarda Demir Eksikliği Anemisini Önleme Yaklaşımları. Çocuk Sağlığı ve Hastalıkları Dergisi 52, 224-231.

[2] Anonim, 2017. Tahıllar ve Diğer Bitkisel Ürünlerin Alan ve Üretim Miktarlar. Türkiye İstatistik Kurumu.

http://www.tuik.gov.tr/UstMenu.do?metod=tem elist (Erişim tarihi: 22.03.2018).

[3] Anonim, 2014. Tahıllar ve Diğer Bitkisel Ürünlerin Alan ve Üretim Miktarlar. Türkiye İstatistik Kurumu. http://www.tuik.gov.tr/UstMenu.do?metod=tem elist (Erişim tarihi: 22.03.2018). 
[4] Doğan R., Yürür, N. 1992. Bursa Yöresinde Yetiștirilen Buğday Çeşitlerinin Verim Komponentleri Yönünden Değerlendirilmesi. Uludă̆ Üniversitesi Ziraat Fakültesi Dergisi, 9, 37-46.

[5] Özkaya, H., Özkaya, B. 2005. Tahıl ve Ürünleri Analiz Yöntemleri. Gıda Teknolojisi Derneği Yayınları, Ankara,157 s.

[6] Fowler, D. B., Brydon, J., Baker, R. J. 1989. Nitrogen Fertilization of No-till Winter Wheat and Rye. II. Influence on Grain Protein. Agronomy Journal, 81, 72-77.

[7] Anonim, 2017. Meteroloji Genel Müdürlüğü Antalya. Meteoroloji İstasyonu, Antalya.

[8] Tonk, F., İştipliler, D., Tosun, M. 2017. Bazı Ekmeklik Buğday (Triticum aestivum L.) Genotiplerinde Özellikler Arası İlişkiler ve Path Analizi. Ege Üniv Ziraat Fak. Dergisi, 54 (1), 8589.

[9] Özseven, İ., Bayram, M., E. 2003. Kate A-1 ve Marmara-86 Ekmeklik Buğday Çeșitlerinde N ve $\mathrm{P}_{2} \mathrm{O}_{5}$ Dozlarının Verim ve Verim Öğelerine Etkileri. Tarla Bitkileri Merkez Araştırma Enstitüsü Dergisi, 12(1-2), 22-41.

[10] Kahraman, T. 2006. Bazı ekmeklik buğday çeşitlerinde farklı ekim zamanı ve azotlu gübreleme uygulamalarının, tane dolum süresi ve tane dolum oranı ile verim ve kalite unsurlarına etkilerinin belirlenmesi. Trakya Üniversitesi Fen Bilimleri Enstitüsü, Doktora tezi, 160 s, Tekirdağ.

[11] Aydın, N., Bayramoğlu, H. O., Mut, Z., Özcan, H. 2005. Ekmeklik Buğday (Triticum aestivum L,) Çeşit ve Genotiplerının Karadeniz Koşullarında Verim ve Kalite Özelliklerinin Belirlenmesi. Ankara Üniversitesi Ziraat Fakültesi Tarım Bilimleri Dergisi, 11(3), 257-262.

[12] Mut, Z., Aydın, N., Bayramoğlu, H. O., Özcan, H. 2007. Bazl Ekmelik Buğday (Triticum aestivum
L.) Genotiplerinin Verim ve Başlıca Kalite Özelliklerinin Belirlenmesi. OMÜ Ziraat Fakültesi Dergisi, 22(2), 193-201.

[13] Ünal, S. S. 2003. Buğday Un ve Kalitesinin Belirlenmesinde Uygulanan Yöntemler, Nevşehir Ekonomisinin Sorunları ve Çözüm Önerileri. Nevşehir Ekonomisi Sempozyumu, 27-28 Haziran, Nevşehir, 15-29.

[14] Işık, A. 2011. Trakya bölgesine uygun verimli ve kaliteli ekmeklik buğday genotiplerinin belirlenmesi. Namık Kemal Üni. Fen Bil. Enst. Yüksek Lisans Tezi, 104s.Tekirdağ.

[15] Aydoğan, S., Soylu, S. 2016. Yetiștirme Koșullarının Bazı Ekmeklik Buğday Ceșitlerinin Kalite Özelliklerine Etkisi. Selçuk Tarım Bilimleri Dergisi, 2(2), 123-127.

[16] Elgün, A., Ertugay, Z., Certel, M., Kotancılar, H. G. 2002. Tahıl ve Ürünlerinde Analitik Kalite Kontrolü ve Laboratuvar Uygulama Klavuzu, Atatürk Üniversitesi Ziraat Fakültesi Yayınları:335, Erzurum, 245 s.

[17] Egesel, C. Ö., Kahrıman, F., Tayyar, Ş., Baytekin, H. 2009. Ekmeklik Buğdayda Un Kalite Özellikleri ile Dane Veriminin Karşılıklı Etkileşimleri ve Uygun Çeşit Seçimi. Anadolu Tarım Bilimleri Dergisi, 24(2), 76-83.

[18] Altuntaş, A., Akgün, İ. 2016. Uşak Koşullarında Kızıltan-91 Buğday Çeşidi Üzerinde Farklı Azot Dozu ve Sıvı Gübre Uygulamalarının Verim ve Verim Unsurlarına Etkisi. Süleyman Demirel Üniversitesi Fen bilimleri Enstitü Dergisi, 20(3), 496-503.

[19] Aydoğan, S., Akçacık, G. A., Şahin, M., Kaya, Y. 2007. Ekmeklik Buğday (T. aestivum L.) Genotiplerinde Verim ve Bazı Kalite Özellikleri Arasındaki İlișkiler. Tarla Bitkileri Merkez Araştırma Enstitüsü Dergisi, 16 (1-2), 21-30. 